\title{
Phenylalanine Kinetics in Sick Preterm Neonates with Respiratory Distress Syndrome
}

\author{
G. J. SHORTLAND, J. H. WALTER, P. J. FLEMING, AND D. HALLIDAY \\ Institute of Child Health, University of Bristol, Bristol, United Kingdom [G.J.S., J.H.W., \\ P.J.F.], and Nutrition Research Group, MRC Clinical Research Centre, Harrow, Middlessex, \\ United Kingdom [D.H.]
}

\begin{abstract}
The cause of hyperphenylalaninemia in sick preterm infants has yet to be determined; one reason may be reduced tolerance to phenylalanine as a consequence of immaturity of phenylalanine hydroxylase. Phenylalanine metabolism was studied in vivo in 23 ventilated preterm infants of gestational age 23 to $36 \mathrm{wk}$ within the first $6 \mathrm{~d}$ of life using a continuous i.v. infusion of the stable isotopelabeled amino acids $\left[{ }^{2} \mathrm{H}_{5}\right]$ phenylalanine, $\left[{ }^{2} \mathrm{H}_{4}\right]$ tyrosine, and $\left[{ }^{2} \mathrm{H}_{2}\right]$ tyrosine. Phenylalanine hydroxylation was calculated from two different methods. In the first method, used in all 23 infants receiving glucose and in seven of these infants who subsequently received parenteral nutrition, phenylalanine hydroxylation was calculated from the plasma enrichments of $\left[{ }^{2} \mathrm{H}_{5}\right]$ phenylalanine and $\left[{ }^{2} \mathrm{H}_{4}\right]$ tyrosine and from the molar ratio of tyrosine to phenylalanine in mammalian tissue protein. In this instance, the mean hydroxylation was 16.0 (SD 10.9) and $48.4(\mathrm{SD} \mathrm{14.9)} \mu \mathrm{mol} / \mathrm{kg} / \mathrm{h}$, which was $17.3 \%$ (SD $8.4 \%$ ) and $33.2 \%$ (SD 9.8\%) of the total phenylalanine flux for infants receiving glucose and parenteral nutrition, respectively. Additionally, in six infants receiving glucose, hydroxylation was calculated from the measured phenylalanine $\left({ }^{2} \mathrm{H}_{5}\right)$, independent tyrosine
\end{abstract}

In normal newborn infants, plasma concentrations of the essential amino acid phenylalanine are less than 200 $\mu \mathrm{mol} / \mathrm{L}$. Concentrations in excess of $400 \mu \mathrm{mol} / \mathrm{L}$ are known to be toxic to the developing brain (1). Such raised levels are characteristic of infants with untreated phenylketonuria and nonphenylketonuria-hyperphenylalaninemia in which there are inherited defects of phenylalanine hydroxylation. More recently, hyperphenylalaninemia has been described in sick preterm infants as a complication of parenteral feeding with amino acid solutions. Although this is a transient phenomenon, levels have been reported in some infants in excess of $1000 \mu \mathrm{mol} / \mathrm{L}(2-5)$. The implications of these high phenylalanine concentrations

Received January 7, 1993; accepted June 2, 1994.

Correspondence and reprint requests: Dr. G. J. Shortland, University Department of Child Health, University Hospital of Wales, Heath Park, Cardiff, CF4 $4 \mathrm{XN}$, Wales, UK.

Supported by a grant from Action Research (S/P/1900). $\left({ }^{2} \mathrm{H}_{2}\right)$ fluxes, and the plasma enrichments of $\left({ }^{2} \mathrm{H}_{5}\right)$ phenylalanine and its hydroxylation product $\left[{ }^{2} \mathrm{H}_{4}\right]$ tyrosine. In this case, hydroxylation was $20.5(\mathrm{SD} 13.0) \mu \mathrm{mol} / \mathrm{kg} / \mathrm{h}$, which represented $22.3 \%$ (SD 9.8\%) of the phenylalanine flux. In the same six infants, phenylalanine hydroxylation derived using the first method was 22.2 (SD 13.1) $\mu \mathrm{mol} / \mathrm{kg} / \mathrm{h}, 23.6 \%$ (SD 9.9\%) of the total phenylalanine flux. The close agreement between phenylalanine hydroxylation calculated from the enrichment of plasma with $\left[{ }^{2} \mathrm{H}_{2}\right]$ tyrosine and estimated from the proportion of phenylalanine to tyrosine in body protein confirms that the independent measurement of tyrosine flux by a constant infusion of $\left[{ }^{2} \mathrm{H}_{2}\right]$ tyrosine is not routinely required in the measurement of phenylalanine hydroxylation in preterm infants. These results do not support the hypothesis that phenylalanine hydroxylase activity is low in preterm infants. (Pediatr Res 36: 713-718, 1994)
Abbreviations
PAH, phenylalanine hydroxylase
MPE, molecule percent excess

over a relatively short period of time are unknown, but, in view of the high risk of fetal damage in maternal hyperphenylalaninemia (6), they may pose a significant risk to the preterm infant.

The cause of hyperphenylalaninemia in such infants has yet to be determined, but it is usually ascribed to a reduced tolerance to phenylalanine as a consequence of immaturity of PAH or enzymes of tyrosine metabolism, in particular 4-(OH)phenylpyruvate dioxygenase (7). Although postmortem studies with fetal hepatic tissue have demonstrated the presence of PAH activity comparable to adult levels from 20 wk of fetal life (8) and low activities of enzymes for tyrosine metabolism (9), there have been no reports of in vivo enzyme activity measurement in preterm infants. To determine the in vivo activity of $\mathrm{PAH}$ in sick preterm infants, we have studied, using stable isotope techniques, the rate of hydroxylation of phenylalanine to tyrosine in 23 such infants receiving intensive care. 


\section{METHODS}

Subjects. Twenty-three infants were studied. Their gestational ages were 23.4 to $36 \mathrm{wk}$ (median $29.7 \mathrm{wk}$ ) as assessed by maternal dates and confirmed by ultrasound scan between 14 and $18 \mathrm{wk}$ of pregnancy. All infants required respiratory support, either intermittent positivepressure ventilation or constant positive airways pressure, for a primary diagnosis of respiratory distress syndrome and received variable amounts of supplemental oxygen. All infants were clinically stable during the course of the studies; no infant had an arterial blood $\mathrm{pH}$ of less than 7.25 or significant intraventricular hemorrhage. No infant had a major congenital abnormality. All infants were being nursed in incubators in a thermoneutral environment.

Of the 23 infants, seven were studied a second time when receiving parental nutrition (Vamin 9 Glucose, Kabi Pharmacia Ltd., Milton Keynes, UK). Individual characteristics of these two groups of infants are summarized in Tables 1 and 2 . At the time of the studies, as part of their routine care, each infant had an indwelling superficial venous catheter in the hand or foot and a peripheral or umbilical arterial catheter for blood sampling. Informed written consent was obtained from all the parents, and the study was approved by the Bristol and Weston District Research Ethical Committee.

Study protocol. Isotopes, L- $\left[\right.$ ring- $\left.{ }^{2} \mathrm{H}_{5}\right]$ phenylalanine, $\mathrm{L}-\left[\right.$ ring- $\left.{ }^{2} \mathrm{H}_{4}\right]$ tyrosine, and $\mathrm{L}-\left[\right.$ ring- $\left.{ }^{2} \mathrm{H}_{2}\right]$ tyrosine (all $98 \%$

Table 1. Description of infants studied receiving glucose*

\begin{tabular}{|c|c|c|c|c|c|}
\hline $\begin{array}{c}\text { Study } \\
\text { no. }\end{array}$ & $\begin{array}{l}\text { Gestation } \\
\text { (wk) }\end{array}$ & $\begin{array}{l}\text { Age } \\
\text { (h) }\end{array}$ & $\begin{array}{c}\text { Birth } \\
\text { weight } \\
\text { (kg) }\end{array}$ & $\begin{array}{c}\text { Study } \\
\text { weight } \\
(\mathrm{kg})\end{array}$ & $\begin{array}{l}\text { Inspired oxygen } \\
\text { concentration } \\
(\%)\end{array}$ \\
\hline 1 & 31.0 & 65.0 & 1.600 & 1.320 & 48.0 \\
\hline 2 & 28.6 & 61.0 & 1.475 & 1.480 & 26.0 \\
\hline 3 & 28.3 & 55.0 & 1.430 & 1.250 & 32.0 \\
\hline 4 & 29.4 & 107.0 & 1.295 & 1.295 & 26.0 \\
\hline 5 & 33.9 & 72.0 & 2.290 & 2.290 & 60.0 \\
\hline 6 & 30.1 & 59.0 & 1.765 & 1.765 & 25.0 \\
\hline 7 & 27.4 & 61.0 & 1.070 & 0.940 & Air \\
\hline 8 & 31.7 & 60.0 & 1.875 & 1.875 & 55.0 \\
\hline 9 & 31.7 & 60.0 & 1.700 & 1.700 & 68.0 \\
\hline 10 & 29.7 & 83.0 & 1.550 & 1.570 & Air \\
\hline 11 & 30.0 & 84.0 & 1.340 & 1.740 & Air \\
\hline 12 & 34.0 & 66.0 & 2.170 & 2.180 & 35.0 \\
\hline 13 & 36.0 & 47.0 & 2.500 & 2.500 & 57.0 \\
\hline 14 & 31.3 & 72.0 & 1.600 & 1.600 & 55.0 \\
\hline 15 & 26.9 & 72.0 & 0.895 & 0.740 & 35.0 \\
\hline 16 & 29.0 & 42.0 & 1.300 & 1.300 & 40.0 \\
\hline 17 & 25.0 & 82.0 & 0.720 & 0.695 & Air \\
\hline 18 & 29.7 & 68.0 & 1.040 & 1.080 & 45.0 \\
\hline 19 & 29.6 & 49.0 & 1.320 & 1.210 & 52.0 \\
\hline 20 & 24.1 & 105.0 & 0.670 & 0.645 & 30.0 \\
\hline 21 & 28.4 & 48.0 & 1.100 & 0.975 & 40.0 \\
\hline 22 & 31.9 & 51.0 & 1.525 & 1.525 & Air \\
\hline 23 & 23.4 & 132.0 & 0.780 & 0.760 & 31.0 \\
\hline Mean & 29.6 & 69.6 & 1.435 & 1.410 & \\
\hline $\mathrm{SD}$ & 3.0 & 21.6 & 0.483 & 0.512 & \\
\hline
\end{tabular}

* The individual gestation at birth (wk), age at the time of study $(\mathrm{h})$, birth weight $(\mathrm{kg})$, and study weight $(\mathrm{kg})$ are shown. In addition, the inspired oxygen concentration (\%) is shown; "Air" indicates that the infants were in room air.
${ }^{2} \mathrm{H}$ ), were obtained from Cambridge Isotopes Laboratories (Woburn, MA). They were dissolved in saline with the exception of $\left[{ }^{2} \mathrm{H}_{2}\right]$ tyrosine, which was in a $10 \%$ dextrose solution. All preparations were shown to be sterile and pyrogen free.

Baseline blood samples were collected, and i.v. priming boluses of $\left[{ }^{2} \mathrm{H}_{4}\right]$ tyrosine $(0.3 \mathrm{mg} / \mathrm{kg})$ and $\left[{ }^{2} \mathrm{H}_{5}\right]$ phenylalanine $(1.8 \mathrm{mg} / \mathrm{kg})$ were given before a $\left[{ }^{2} \mathrm{H}_{5}\right]$ phenylalanine continuous infusion $(1.8 \mathrm{mg} / \mathrm{kg} / \mathrm{h})$ in all study subjects for 6 to $8 \mathrm{~h}$ whether subjects were receiving dextrose or parental nutrition. In six subjects receiving dextrose, an i.v. bolus of $\left[{ }^{2} \mathrm{H}_{2}\right]$ tyrosine $(0.25 \mathrm{mg} / \mathrm{kg})$ followed by a continuous infusion of $\left[{ }^{2} \mathrm{H}_{2}\right]$ tyrosine $(0.25 \mathrm{mg} / \mathrm{kg} / \mathrm{h})$ was also given concurrently. All infusions were through the indwelling venous catheter and were delivered by an accurately calibrated syringe pump (model 711, Ivac, San Diego, CA) at rates between 0.4 and $1.2 \mathrm{~mL} / \mathrm{h}$. One hundred to $250 \mu \mathrm{L}$ of whole blood were sampled through the indwelling arterial catheter, kept patent by an infusion of heparinized saline, at hourly intervals from $2 \mathrm{~h}$ after the commencement of the infusion. To reduce the amount of blood sampled in those infants of less than $1500 \mathrm{~g}$, the number of samples taken was reduced to one baseline and three hourly samples taken during the last $3 \mathrm{~h}$ of the infusion. Blood was immediately centrifuged and the plasma stored at $-20^{\circ} \mathrm{C}$ until required for analysis.

Analytical methods. Plasma phenylalanine and tyrosine were derivatized to their t-butyldimethylsilyl derivatives, and their concentrations and deuterium enrichments were determined by electron ionization gas chromatography-mass spectrometry using selected ion monitoring and $\beta$-methylphenylalanine or $\alpha$-methyltyrosine as internal standards, respectively, with a method similar to that described previously (10). Final values for all determinations were corrected using calibration curves for enrichments and concentrations. Isotopic enrichment was expressed as MPE.

Model description. Phenylalanine is an essential amino acid and therefore available only through dietary sources (11). It is metabolized to tyrosine by hydroxylation of the phenyl ring at position 4 primarily in the liver, although some hydroxylase activity exists in kidney and pancreas in adults (12). No conversion of tyrosine to phenylalanine is possible in vivo.

The model assumes that the free phenylalanine and tyrosine pools are homogeneous and in rapid equilibrium, that in the fasting state phenylalanine enters the pool only from protein catabolism, and that the only pathways of phenylalanine removal from the pool are to protein synthesis and by hydroxylation to tyrosine.

In the infant not receiving supplemental amino acids via parenteral nutrition, the total flux of the infused amino acid $(\mathrm{Q} ; \mu \mathrm{mol} / \mathrm{kg} / \mathrm{h})$ can be calculated from isotope dilution principles using the following equation:

$$
\mathrm{Q}=\mathrm{i} \cdot(\mathrm{Ei} / \mathrm{Ep})
$$

where $i$ is the rate of infusion of the tracer $(\mu \mathrm{mol} / \mathrm{kg} / \mathrm{h})$ and $\mathrm{Ei}$ and $\mathrm{Ep}$ are the enrichments of the infusate and of 
Table 2. Description of infants studied while receiving parenteral nutrition*

\begin{tabular}{cccccccc}
\hline Study no. & $\begin{array}{c}\text { Gestation } \\
(\mathrm{wk})\end{array}$ & Age $(\mathrm{h})$ & $\begin{array}{c}\text { Birth } \\
\text { weight }(\mathrm{kg})\end{array}$ & $\begin{array}{c}\text { Study } \\
\text { weight }(\mathrm{kg})\end{array}$ & $\begin{array}{c}\text { Inspired oxygen } \\
\text { concentration }(\%)\end{array}$ & $\begin{array}{c}\text { Protein intake } \\
(\mathrm{g} / \mathrm{d})\end{array}$ & $\begin{array}{c}\text { Phenylalanine } \\
\text { intake }(\mu \mathrm{mol} / \mathrm{kg} / \mathrm{h})\end{array}$ \\
\hline 8 & 31.7 & 219.0 & 1.875 & 1.650 & 46.0 & 1.9 & 44.8 \\
9 & 31.7 & 146.0 & 1.700 & 1.480 & 30.0 & 2.6 & 60.6 \\
16 & 29.0 & 128.0 & 1.300 & 1.150 & 40.0 & 2.3 & 55.4 \\
17 & 25.0 & 82.0 & 0.720 & 0.695 & 20.9 & 2.0 & 47.6 \\
19 & 29.6 & 148.0 & 1.320 & 1.150 & 40.0 & 2.4 & 56.5 \\
20 & 24.1 & 225.0 & 0.670 & 0.625 & 40.0 & 1.3 & 35.8 \\
23 & 23.4 & 204.0 & 0.780 & 0.725 & 31.0 & 2.2 & 51.5 \\
Mean & 27.8 & 164.6 & 1.195 & 1.068 & & 2.1 & 50.3 \\
SD & 3.5 & 53.1 & 0.486 & 0.403 & & 0.4 & 8.4 \\
\hline
\end{tabular}

* The individual gestation at birth (wk), age at the time of study (h), birth weight $(\mathrm{kg})$, and study weight $(\mathrm{kg})$ are shown. Inspired oxygen concentration (\%), amount of protein received $(\mathrm{g} / \mathrm{d})$, and phenylalanine intake $(\mu \mathrm{mol} / \mathrm{kg} / \mathrm{h})$ from the parenteral nutrition are also shown.

the amino acid, respectively, in plasma at isotopic plateau. The rate of phenylalanine conversion to tyrosine $(\mathrm{Qpt} ; \mu \mathrm{mol} / \mathrm{kg} / \mathrm{h})$ can be derived similarly:

$$
\mathrm{Qpt}=\mathrm{Qt} \cdot(\mathrm{Et} / \mathrm{Ep})
$$

where Qt is tyrosine flux $(\mu \mathrm{mol} / \mathrm{kg} / \mathrm{h})$ estimated independently by the primed constant infusion of $\left[{ }^{2} \mathrm{H}_{2}\right]$ tyrosine and Et and Ep are the enrichments of $\left[{ }^{2} \mathrm{H}_{5}\right]$ phenylalanine and $\left[{ }^{2} \mathrm{H}_{4}\right]$ tyrosine, respectively, in plasma. Given that tyrosine has limited solubility, it is beneficial if the phenylalanine conversion to tyrosine can be calculated without the need for a separate estimation of tyrosine flux. It can be assumed that the movement of any two amino acids into and out of protein will be of a constant ratio that will be related to the amino acid composition of the protein (13); therefore,

$$
\mathrm{Qt}=[\mathrm{Qp} \cdot(\mathrm{Pt} / \mathrm{Pp})]+\mathrm{Qpt}
$$

where $\mathrm{Pt} / \mathrm{Pp}$ is the molar ratio of the fluxes of tyrosine and phenylalanine arising from protein catabolism. This ratio has been derived from the measured protein amino acid composition of mammalian tissue and found to be 0.73 (14). Qp is the phenylalanine flux $(\mu \mathrm{mol} / \mathrm{kg} / \mathrm{h})$. By combining equations 2 and 3, Qpt can be calculated without measuring the tyrosine flux separately:

$$
\mathrm{Qpt}=(\mathrm{Pt} / \mathrm{Pp}) \cdot \mathrm{Qp} \cdot \frac{1}{[(\mathrm{Ep} / \mathrm{Et})-1]}
$$

These formulas for infants not receiving parenteral nutrition are similar to those published previously (15), but no correction is made for the infusion of phenylalanine and tyrosine isotopes because we wished to measure total phenylalanine flux, tyrosine flux, and phenylalanine hydroxylation, which will necessarily include the infused phenylalanine and tyrosine labeled tracers. At steady state, in infants fed dextrose solutions only, the sole other source of phenylalanine will be protein catabolism. This can be measured with the following formula:

$$
\mathrm{Qp}(\text { protein })=\mathrm{Qp}-\mathrm{ip}
$$

where $\mathrm{Qp}$ (protein) is the phenylalanine entering the amino acid pool from protein catabolism and ip is the infusion of the phenylalanine tracer.
In those infants receiving parenteral nutrition, phenylalanine flux can be calculated from equation 1 . Phenylalanine production from protein catabolism is determined wtih the following formula:

$$
\mathrm{Qp}(\text { protein })=\mathrm{Qp}-\text { ip }- \text { Phe(tpn })
$$

where Phe(tpn) is the amount of phenylalanine entering the infant by i.v. nutrition $(\mu \mathrm{mol} / \mathrm{kg} / \mathrm{h})$. In the infants receiving parenteral nutrition, equation 3 becomes

$$
\mathrm{Qt}=[\mathrm{Qp} \cdot(\mathrm{Pt} / \mathrm{Pp})]+\mathrm{Qpt}+\operatorname{Tyr}(\mathrm{tpn})
$$

where Tyr(tpn) is the amount of tyrosine entering the infant by i.v. nutrition. Thus, combining equations 7 and 2 , phenylalanine hydroxylation for the infant receiving i.v. nutrition is

$$
\mathrm{Qpt}=[\mathrm{Qp} \cdot(\mathrm{Pt} / \mathrm{Pp})+\operatorname{Tyr}(\mathrm{tpn})] /[(\mathrm{Ep} / \mathrm{Et})-1]
$$

Statistics. All values are expressed as mean $\pm 1 \mathrm{SD}$. Significance tests were performed using a Wilcoxon signed rank test.

\section{RESULTS}

Amino acid concentrations. Phenylalanine concentrations were $72(40.7) \mu \mathrm{mol} / \mathrm{L}$ and $103(35.4) \mu \mathrm{mol} / \mathrm{L}$ for those infants receiving glucose and those receiving parenteral nutrition, respectively.

Phenylalanine turnover. The majority of studies were completed within $6 \mathrm{~h}$, the longest lasting $8 \mathrm{~h}$. All studies reached plateaus as judged by visual inspection for phenylalanine concentrations and enrichments.

For infants studied while receiving only glucose, coefficients of variation at plateaus were less than $11.4 \%$ [mean $5.3 \%(3.1 \%)$ ] for phenylalanine enrichments. Mean enrichments for $\left[{ }^{2} \mathrm{H}_{5}\right]$ phenylalanine were 12.4 (2.8) MPE, and a plateau was reached by $6 \mathrm{~h}$ with priming of the $\left[{ }^{2} \mathrm{H}_{5}\right.$ ]phenylalanine pool before commencing the $\left[{ }^{2} \mathrm{H}_{5}\right]$ phenylalanine infusions. Calculated rates of total phenylalanine flux were $87.6(17.3) \mu \mathrm{mol} / \mathrm{kg} / \mathrm{h}$. Phenylalanine entering the plasma pool from protein catabolism was $76.9(17.3) \mu \mathrm{mol} / \mathrm{kg} / \mathrm{h}$.

For infants studied while receiving parental nutrition, mean coefficient of variation at plateaus was $5.1 \%(3.4 \%)$ for phenylalanine enrichments. Mean enrichment for 
$\left[{ }^{2} \mathrm{H}_{5}\right]$ phenylalanine was 7.6 (0.9) MPE, and a plateau was reached by $6 \mathrm{~h}$ with priming of the $\left[{ }^{2} \mathrm{H}_{5}\right]$ phenylalanine pool before commencing the $\left[{ }^{2} \mathrm{H}_{5}\right]$ phenylalanine infusions. The calculated rate of total phenylalanine flux was $145.6(9.4) \mu \mathrm{mol} / \mathrm{kg} / \mathrm{h}$. The rate of phenylalanine entering the plasma pool from protein catabolism was 84 (16.2) $\mu \mathrm{mol} / \mathrm{kg} / \mathrm{h}$.

Tyrosine turnover. In the infants receiving glucose alone, enrichment for $\left[{ }^{2} \mathrm{H}_{4}\right]$ tyrosine was $2.2(0.5) \mathrm{MPE}$ and for $\left[{ }^{2} \mathrm{H}_{2}\right]$ tyrosine 1.6 (0.5) MPE. In infants receiving parenteral nutrition, enrichment for $\left[{ }^{2} \mathrm{H}_{5}\right]$ tyrosine was 2.3 (0.5) MPE.

Phenylalanine hydroxylation. In 23 infants receiving glucose alone, phenylalanine hydroxylation was derived as $16.0(10.9) \mu \mathrm{mol} / \mathrm{kg} / \mathrm{h}$, which was $17.3 \%(8.4 \%)$ of the total phenylalanine flux. In those infants in whom tyrosine flux was measured separately using $\left[{ }^{2} \mathrm{H}_{2}\right]$ tyrosine, phenylalanine hydroxylation was $20.5(13.0) \mu \mathrm{mol} / \mathrm{kg} / \mathrm{h}$, which was $22.3 \%(9.8 \%)$ of the total phenylalanine flux. In the same six infants, the derived value using the constant ratio between tyrosine and phenylalanine was $22.2(13.1) \mu \mathrm{mol} / \mathrm{kg} / \mathrm{h}$; this was $23.6 \%(9.9 \%)$ of the total phenylalanine flux. There was no significant difference between these two values $(p>0.1)$. For a full summary of the results, see Table 3 .

In the seven infants who were also studied while receiving parenteral nutrition, phenylalanine hydroxylation was derived as $48.4(14.9) \mu \mathrm{mol} / \mathrm{kg} / \mathrm{h}$, which was $33.2 \%$ $(9.8 \%)$ of the total phenylalanine flux. For a full summary of the results, see Table 4.

\section{DISCUSSION}

Previously reported levels of amino acids in preterm infants receiving parenteral nutrition included a number with increased plasma phenylalanine concentrations $(3-5,16)$. In contrast, Clark et al. (17) found a low incidence of increased phenylalanine concentrations, with only one infant out of 109 very low birth weight babies receiving parenteral nutrition having a concentration greater than $600 \mu \mathrm{mol} / \mathrm{L}$, although a number of infants were found to have increased tyrosine levels.

The implications of increased phenylalanine concentrations for newborn infants over a short period are unknown, but the consequences to the fetus of maternal hyperphenylalaninemia are known to be severe $(6,18)$. Published case reports also raise the possibility of neurologic damage related to high tyrosine levels in the newborn $(19,20)$.

Factors responsible for the increased concentrations of phenylalanine and tyrosine may include rapid infusions of parenteral amino acids, liver disease, sepsis, and inadequate calorie intake (21). Additionally, in the preterm neonate, immaturity of enzymes concerned with the metabolism of phenylalanine and tyrosine, particularly $\mathrm{PAH}$, tyrosine aminotransferase, and 4-hydroxyphenylpyruvate dioxygenase, may theoretically be responsible. PAH controls the hydroxylation of phenylalanine to tyrosine, the major pathway for metabolism of phenylalanine not incorporated into body protein. To assess in vivo in sick preterm infants the maturity of this enzyme,

Table 3. Summary of results for infants receiving glucose

\begin{tabular}{|c|c|c|c|c|c|}
\hline Study no. & $\begin{array}{l}\text { Phenylalanine flux } \\
(\mu \mathrm{mol} / \mathrm{kg} / \mathrm{h})\end{array}$ & $\begin{array}{l}\text { Phenylalanine production } \\
\text { from protein catabolism } \\
(\mu \mathrm{mol} / \mathrm{kg} / \mathrm{h})\end{array}$ & $\begin{array}{c}\text { Phenylalanine hydroxylation } \\
\text { calculated from } \\
{\left[{ }^{2} \mathrm{H}_{4}\right] \text { tyrosine enrichments }} \\
(\mu \mathrm{mol} / \mathrm{kg} / \mathrm{h})\end{array}$ & $\begin{array}{c}\text { Phenylalanine } \\
\text { hydroxylation as a } \\
\text { percentage of total } \\
\text { phenylalanine flux (\%) }\end{array}$ & $\begin{array}{l}\text { Phenylalanine hydroxylation } \\
\text { calculated from } \\
{\left[{ }^{2} \mathrm{H}_{2}\right] \text { tyrosine enrichments }} \\
(\mu \mathrm{mol} / \mathrm{kg} / \mathrm{h})\end{array}$ \\
\hline 1 & 92.2 & 78.8 & 9.9 & 10.8 & \\
\hline 2 & 109.7 & 98.9 & 19.1 & 17.4 & \\
\hline 3 & 90.7 & 78.5 & 10.7 & 11.8 & \\
\hline 4 & 57.3 & 46.3 & 7.6 & 13.2 & \\
\hline 5 & 111.3 & 101.3 & 15.9 & 14.3 & \\
\hline 6 & 95.6 & 84.7 & 23.4 & 24.5 & \\
\hline 7 & 81.1 & 70.1 & 9.3 & 11.4 & \\
\hline 8 & 92.9 & 82.8 & 15.4 & 16.6 & \\
\hline 9 & 94.3 & 83.7 & 21.0 & 22.3 & \\
\hline 10 & 77.2 & 67.4 & 8.7 & 11.3 & \\
\hline 11 & 75.5 & 67.1 & 7.6 & 10.0 & \\
\hline 12 & 65.5 & 54.9 & 7.3 & 11.2 & \\
\hline 13 & 102.9 & 91.8 & 17.4 & 16.9 & \\
\hline 14 & 59.9 & 48.9 & 6.0 & 10.0 & \\
\hline 15 & 120.5 & 111.4 & 57.2 & 47.4 & 45.7 \\
\hline 16 & 79.8 & 69.1 & 11.1 & 13.9 & 10.8 \\
\hline 17 & 101.3 & 90.6 & 26.7 & 26.3 & \\
\hline 18 & 64.9 & 55.3 & 14.1 & 21.7 & 15.9 \\
\hline 19 & 97.4 & 87.9 & 26.6 & 27.4 & 27.8 \\
\hline 20 & 108.0 & 97.1 & 21.2 & 19.6 & \\
\hline 21 & 85.8 & 73.9 & 13.0 & 15.2 & 11.4 \\
\hline 22 & 72.7 & 62.2 & 11.4 & 15.7 & 11.7 \\
\hline 23 & 78.8 & 67.6 & 8.4 & 10.7 & \\
\hline Mean & 87.6 & 76.9 & 16.0 & 17.3 & 20.5 \\
\hline SD & 17.3 & 17.4 & 10.9 & 8.4 & 13.8 \\
\hline
\end{tabular}


Table 4. Summary of results for infants receiving parenteral nutrition

\begin{tabular}{|c|c|c|c|c|}
\hline Study no. & $\begin{array}{l}\text { Phenylalanine flux } \\
\qquad(\mu \mathrm{mol} / \mathrm{kg} / \mathrm{h})\end{array}$ & $\begin{array}{l}\text { Phenylalanine production } \\
\text { from protein catabolism } \\
(\mu \mathrm{mol} / \mathrm{kg} / \mathrm{h})\end{array}$ & $\begin{array}{l}\text { Phenylalanine hydroxylation } \\
\text { calculated from } \\
{\left[{ }^{2} \mathrm{H}_{4}\right] \text { tyrosine enrichments }} \\
(\mu \mathrm{mol} / \mathrm{kg} / \mathrm{h})\end{array}$ & $\begin{array}{c}\text { Phenylalanine hydroxylation } \\
\text { as a percentage of total } \\
\text { phenylalanine flux }(\%)\end{array}$ \\
\hline 8 & 163.1 & 107.3 & 50.9 & 31.2 \\
\hline 9 & 138.1 & 65.9 & 41.4 & 30.0 \\
\hline 16 & 139.2 & 71.5 & 54.0 & 38.8 \\
\hline 17 & 141.0 & 82.7 & 24.1 & 17.1 \\
\hline 20 & 152.3 & 105.3 & 52.6 & 34.6 \\
\hline 23 & 137.9 & 74.3 & 42.6 & 30.9 \\
\hline Mean & 145.6 & 84.0 & 48.4 & 33.2 \\
\hline $\mathrm{SD}$ & 9.4 & 16.2 & 14.9 & 9.8 \\
\hline
\end{tabular}

we have measured the conversion of phenylalanine to tyrosine using primed constant infusions of the stable isotopes $\left[{ }^{2} \mathrm{H}_{5}\right]$ phenylalanine, $\left[{ }^{2} \mathrm{H}_{4}\right]$ tyrosine, and $\left[{ }^{2} \mathrm{H}_{2}\right]$ tyrosine.

By restricting the frequency of blood sampling and using micromethods for analysis, we have found it possible to adapt stable isotope techniques to measure phenylalanine flux, tyrosine flux, and phenylalanine hydroxylation in sick preterm infants. The amount of $\left[{ }^{2} \mathrm{H}_{5}\right]$ phenylalanine infused per kilogram body weight was higher than that previously reported for adult studies. In preliminary work, we had found that lower infusion rates of $\left[{ }^{2} \mathrm{H}_{5}\right.$ ]phenylalanine resulted in plasma tyrosine $\left({ }^{2} \mathrm{H}_{4}\right)$ enrichments that were too low to measure with sufficient precision.

For the calculation of phenylalanine hydroxylation, we assumed a constant relationship between the breakdown of protein to phenylalanine and to tyrosine based on the proportion of these two amino acids in body protein (14). We were able to validate this assumption by measuring tyrosine flux independently in six infants using a $\left[{ }^{2} \mathrm{H}_{2}\right]$ tyrosine infusion. The close relation between phenylalanine hydroxylation calculated from the enrichment of plasma with $\left[{ }^{2} \mathrm{H}_{2}\right]$ tyrosine and estimated from the proportion of phenylalanine to tyrosine in body protein ( 20.5 and $21.3 \mu \mathrm{mol} / \mathrm{kg} / \mathrm{h}$, respectively, $p>0.1$ ) confirms that the independent measurement of tyrosine flux by a constant infusion of $\left[{ }^{2} \mathrm{H}_{2}\right]$ tyrosine is not routinely required in the measurement of phenylalanine hydroxylation in preterm infants as in adults (15).

Our model assumes that phenylalanine is lost primarily from the plasma pool to protein synthesis or is converted to tyrosine by hydroxylation. Walker and Mills (22) have reported significant concentrations of metabolites arising from minor catabolic pathways for phenylalanine in the urine of preterm infants receiving parenteral nutrition. Values were varied, which may be explained at least partly by the high rates of amino acid infusion. Infants in the study were given their full daily parenteral nutrition by infusion over 6 to $12 \mathrm{~h}$. If such losses were significant for infants during our studies, although the amount of phenylalanine leaving the plasma pool for protein synthesis would be altered, the calculations for phenylalanine flux, hydroxylation, and production from protein catabolism would not be altered.
No infant had plasma phenylalanine concentrations that would be considered toxic to the CNS. A number of infants had low phenylalanine concentrations of less than $50 \mu \mathrm{mol} / \mathrm{L}$, which were similar to values previously reported in infants receiving dextrose or amino acids at the level of $1.5 \mathrm{~g} / \mathrm{kg} / \mathrm{d}(17)$.

In fasted adults, mean phenylalanine production rates from protein catabolism have been found to be 31.4 (15) and $39.92 \mu \mathrm{mol} / \mathrm{kg} / \mathrm{h}(25)$. For the preterm infants in this study, the mean production rate of phenylalanine from protein catabolism was much greater at 76.9 and 84 $\mu \mathrm{mol} / \mathrm{kg} / \mathrm{h}$ in infants receiving glucose and parenteral nutrition, respectively, suggesting a rapid rate of phenylalanine production from protein breakdown. Limited data from research in seven normal growing newborns aged $20 \mathrm{~d}$ have been reported with endogenous production rates of phenylalanine equal to a mean of $87 \mu \mathrm{mol} / \mathrm{kg} / \mathrm{h}$ (23). In 12 low-birth-weight infants, the phenylalanine flux, calculated from infusions of $\mathrm{L}-\left[1-{ }^{13} \mathrm{C}\right]$ phenylalanine, during enteral and parenteral feeding was 106 and 56 $\mu \mathrm{mol} / \mathrm{kg} / \mathrm{h}$, respectively (24).

Phenylalanine hydroxylation as calculated from $\left[{ }^{2} \mathrm{H}_{2}\right]$ tyrosine enrichments was $16.0 \mu \mathrm{mol} / \mathrm{kg} / \mathrm{h}$, which was $17.3 \%$ of the total phenylalanine turnover rate in infants receiving glucose. In those infants receiving parenteral nutrition, this was further increased to 48.4 $\mu \mathrm{mol} / \mathrm{kg} / \mathrm{h}$, which was $33.2 \%$ of the total phenylalanine turnover rate. Thus, infants are able to respond with an increase in phenylalanine load from i.v. nutrition by increasing the amount of phenylalanine conversion to tyrosine. The difference in rates of phenylalanine hydroxylation for the seven infants studied while receiving glucose and then i.v. nutrition was significant ( $p$ $<0.05$ ).

For fasted adults, Clarke and Bier (25), using separate $\left[{ }^{2} \mathrm{H}_{5}\right]$ phenylalanine and $\left[{ }^{13} \mathrm{C}\right]$ tyrosine infusions, calculated a mean value of $5.8 \mu \mathrm{mol} / \mathrm{kg} / \mathrm{h}$, which accounted for $16.4 \%$ of the total mean phenylalanine turnover rate. Thompson et al. (15) also found that the hydroxylation values for adults were lower at $5.5 \mu \mathrm{mol} / \mathrm{kg} / \mathrm{h}$. In relation to values for term infants, previous work has demonstrated similar hydroxylation rates of $22 \mu \mathrm{mol} / \mathrm{kg} / \mathrm{h}$ for conversion of phenylalanine to tyrosine. This constituted $25 \%$ of the total phenylalanine flux (24). 
The estimation of the rate of phenylalanine conversion to tyrosine depends on the assumption that the free phenylalanine and tyrosine pools are homogeneous and in rapid equilibrium throughout the body. Because the major hydroxylation site in humans is the liver, it is particularly important that the phenylalanine and tyrosine enrichments in plasma are the same as the hepatic intracellular enrichments. Previous authors have raised the possibility that there is delayed equalization of the $\left[{ }^{2} \mathrm{H}_{5}\right]$ phenylalanine with the intrahepatic $\mathrm{PAH}$ pool (25) and also that there may be dilution of the tracer as a result of local intracellular protein degradation. Both of these would result in an underestimate of the rate of phenylalanine conversion to tyrosine as calculated by our method and not produce an artificially high level. From our studies, with a plateau for $\left[{ }^{2} \mathrm{H}_{4}\right]$ tyrosine being reached within 4 to $8 \mathrm{~h}$, we would suggest that equalization with the hydroxylase substrate pool was achieved.

In summary, we measured phenylalanine turnover, tyrosine turnover, and phenylalanine hydroxylation rates in sick preterm infants in the fasting state and while receiving parenteral nutrition. Phenylalanine hydroxylation rates equaled or exceeded those found in adults and increased with the phenylalanine load of parenteral nutrition. These results do not support the hypothesis that PAH activity is low in preterm infants. Transiently high levels of phenylalanine and tyrosine in preterm infants are more likely due to immaturity of enzymes for tyrosine metabolism.

Acknowledgments. The authors thank S. Bartlett and P. Bannister (Nutrition Research Group, MRC Clinical Research Centre, Harrow, Middlesex, UK) for their technical support.

\section{REFERENCES}

1. Smith I, Beasley, Ades AE 1990 Intelligence and quality of dietary treatment in phenylketonuria. Arch Dis Child 65:472-478

2. Mitton SG, Burston D, Brueton MJ 1988 Hyperphenylalaninemia in parenterally fed newborn infants. Lancet 2:1497-1498

3. Evans SJ, Wynne-Williams TCJE, Russell CA, Fairbrother A 1986 Hyperphenylalaninemia in parenterally fed newborn babies. Lancet $2: 1404$
4. Puntis JWL, Edwards MA, Green A, Morgan I, Booth IW, Ball PA 1986 Hyperphenylalaninemia in parenterally fed newborn babies. Lancet 2:1105

5. Walker V, Hall MA, Bulusu S, Allan A 1986 Hyperphenylalaninemia in parenterally fed newborn babies. Lancet 2:1284

6. Lenke RR, Levy HL 1980 Maternal phenylketonuria and hyperphenylalaninemia. An international survey of untreated and treated pregnancies. $\mathrm{N}$ Engl $\mathrm{J}$ Med 303:1202-1208

7. Ohisalo JJ, Laskowska-Klita T, Andersson SM 1982 Development of tyrosine aminotransferase and p-hydroxyphenylpyruvate dioxygenase activities in fetal and neonatal human liver. J Clin Invest 70:198-200

8. Jakubovic A 1971 Phenylalanine hydroxylating system in the human fetus at different developmental ages. Biochem Biophys Acta 237:469-475

9. Andersson SM, Raiha CR, Ohisalo JJ 1980 Regulation tyrosine aminotransferase in foetal rat liver. Biochem J 186:609-612

10. Schwenk WF, Berg PJ, Beaufrere B, Miles JM, Haymond MW 1984 Use of t-butyldimethylsilylation in the gas chromatographic/mass spectrometric analysis of physiologic compounds found in plasma using electron-impact ionisation. Anal Biochem 141:101-109

11. Womack M, Rose WC 1934 Feeding experiments with mixtures of highly purified amino acids. VI. The relation of phenylalanine and tyrosine to growth. J Biol Chem 107:449-458

12. Tourian AJ, Goddard J, Puck TT 1969 Phenylalanine hydroxylase activity in mammalian cells. J Cell Physiol 73:159-170

13. Waterlow JC, Garlick PJ, Millward DJ 1978 Protein turnover in mammalian tissues and in the whole body. North-Holland, Amsterdam, pp 179-245

14. Munro HN, Fleck A 1969 Analysis of tissues and body fluids for nitrogenous constituents. In: Munro HN (ed) Mammalian Protein Metabolism, Vol 3. New York, Academic Press, pp 423-525

15. Thompson GN, Pacy PJ, Merritt H, Ford GC, Read MA, Cheng KN, Halliday D 1989 Rapid measurement of whole body and forearm protein turnover using a ${ }^{2} \mathrm{H}_{5}$ phenylalanine model. Am J Physiol 256:E631-E639

16. McIntosh N, Mitchell V 1990 A clinical trial of two parenteral nutrition solutions in neonates. Arch Dis Child 65:692-699

17. Clark D, Henderson M, Smith M, Dear PRF 1989 Plasma amino acid concentrations in parenterally fed preterm infants. Arch Dis Child 64:939-942

18. Levy HL, Waisbren SE 1983 Effects of untreated maternal phenylketonuria and hyperphenylalaninemia on the fetus. N Engl J Med 309:1269-1274

19. Mammunes P, Prince PE, Thornton NH, Hunt PA, Hitchcock ES 1976 Intellectual deficits after transient tyrosinemia in the term neonate. Pediatrics $57: 675-680$

20. Stoerner JW, Butler IJ, Morriss FH, Howell RR, Seifert WE, Capridi RM, Adcock EW, Denson SE 1980 CSF neurotransmitter studies: an infant with ascorbic acid-responsive tyrosinemia. Am J Dis Child 134:492-494

21. Stutchfield PR, Isherwood DM, Weindling AM 1987 Hyperphenylalaninemia in parenterally fed newborn infants. Lancet 2:1027

22. Walker V, Milis GA 1990 Metabolism of intravenous phenylalanine by babies born before 33 weeks of gestation. Biol Neonate 57:155-166

23. Denne SC, Karn CA, Liu YM, Liechty EA 1992 Phenylalanine kinetics in normal growing newborns during fasting and feeding. Pediatr Res 31(suppl):1707(abstr)

24. Wykes LJ, Ball RO, Menendez CE, Ginther MD, Pencharz PB 1992 Glycine, leucine, and phenylalanine flux in low-birth-weight infants during parenteral and enteral feeding. Am J Clin Nutr 55:971-975

25. Clarke JTR, Bier DM 1982 The conversion of phenylalanine to tyrosine in man. Direct measurement by continuous intravenous tracer infusions of $\mathrm{L}-\left[\right.$ ring $\left.-{ }^{2} \mathrm{H}_{5}\right]$ phenylalanine and $\mathrm{L}-\left[1-{ }^{13} \mathrm{C}\right]$ tyrosine in the postabsorptive state. Metabolism 31:999-1005 